\title{
The Path and Strategy of Linkage Development of Vocational Education Group and Regional Economy*
}

\author{
Jie Liu \\ Urumqi Vocational University \\ Urumqi, China
}

\begin{abstract}
In the process of deepening education reform comprehensively, China's related departments have conducted a proper exploration on the collectivization school-running model of vocational education group, and have achieved phase results. However, compared with the developed countries, we still stay at a low level as a whole. The loose organizational forms obviously exist in the process of the actual school-running, which fails to exert the role vocational education to provide effective support for the development of regional economy. Therefore, in the course of reforming and innovating educational organization activities in the new era, we can actively explore the measures for the linkage development of the vocational education group and regional economy, make them form joint force for the linkage development, improve the actual effect of interactive development in an all-round way, and gradually promote the level of the regional economic development in China.
\end{abstract}

Keywords—vocational education group; regional economy; linkage development

\section{INTRODUCTION}

The reports of the 19th National Congress of the Communist Party of China proposed that we should give priority to the development of education, properly perfect the vocational education system, and improve the quality of vocational education. The State Council has also issued the Decision of the State Council on Accelerating the Development of Modern Vocational Education, and put forward that in the current social context, we must correctly realize the importance of vocational education, develop the advantages of multiple subjects to set up a vocational education group, innovate the development mechanism of the vocational education group, make the vocational education group present a new vitality, formulate a sound vocational education model, and effectively improve the effectiveness of education. Therefore, it is very necessary for us to analyze the construction of vocational education group in new ear,

*Projects supported by the achievements

Project 1: Key project of World Bank of Urumqi Vocational University in 2016: Research on development strategy of Urumqi Vocational Education Group (project number: 2016XZ002);

Project 2: *** research projects in 2017: Research on path of vocational and technical education to promote **poverty alleviation and employment (project number: 17ZJFL028)

Project 3: Key project of development strategy research project of The Chinese Society of Vocational and Technical Education in 2010: Research on strengthening the social attractiveness of higher vocational colleges in Xinjiang (project number: ZLZ04). optimize the vocational education system in combination with the construction of vocational education group, strive to develop a new educational development effect under the support of the linkage development of vocational education group and regional economy, and drive the development of the regional economy, so as to achieve modernization in China.

\section{SCHOOL-RUNNING MODEL OF VOCATIONAL EDUCATION GROUP}

The school-running model of vocational education group mainly takes the group as the carrier for vocational education and vocational education activities as the basic content, so as to construct a collective vocational education system, realize resources sharing and improvement of education quality, highlight the scientificity and pertinence of talent training, and comprehensively improve the overall development effectiveness of talent training. Since the development of collectivization school-running of vocational education in China, its new development modes mainly include regional vocational education group, foreign-related vocational education group, industry-type vocational education group, characteristic vocational education group, and so on[1]. Based on different main components, the basic types of vocational education group can be divided into university-dominant type, enterprise-dominant type, and government-dominant type. Based on different operation modes, the vocational education group can be divided into entity type, alliance type and so on. In the course of the school-running of vocational education group, in order to comprehensively improve the effectiveness of talent training, we need to conduct a proper analysis in combination with different modes, formulate scientific and reasonable talent training plan, strive to build students into high-quality talents who can adapt to the development of regional economy, effectively promote the scientific development of talent cultivation work, and lay a foundation for systematic innovation of talent training in the vocational education system.

\section{ThE CURRENT DEVELOPMENT SituATION OF SCHOOL- RUNNING MODEL OF VOCATIONAL EDUCATION MODEL}

Under the background of comprehensively promoting the reform and development of vocational education in China, the vocational education group has obtained corresponding opportunities in the development of school-running. Based on continuous exploration and analysis on different regions 
combined with actual conditions in the local region, the vocational education group has achieved initial results, and the overall quality of education has been significantly improved. The following is a proper analysis of current development situation of the school-running model of vocational education group in China:

\section{A. The Development Model of the School-running Model of Vocational Education Group in China}

Collectivization school-running is an essential realization form that is produced from practice and promotes the coordinated development of multiple subjects in vocational education in China. China began to explore the school-running model of vocational education group in 1992, and established the first vocational education group in October, 1992, that is, Beijing Xicheng Tourism Vocational Education Group, and subsequently set up corresponding vocational education groups throughout the country. By the end of 2016, there were 1,406 vocational education groups in the country, including 1,095 industrial vocational education groups and 311 regional vocational education groups, which respectively accounted for 77.88 percent and 22.12 percent of the total ${ }^{1}$. Today, China has achieved remarkable achievements in the school-running model of vocational education group during its development. In the new era, as the country further puts emphasis on the running school model of vocational education group and introduces a series of promotion measures, the school-running of vocational education group has also obtained good development prospects and equipped with obvious development advantage, which can gradually achieve the goal of stable development in the new era.

\section{B. The Main Development Scale of School-running Activities of Vocational Education Group}

Under the circumstances that vocational education has been highly valued and has developed vigorously, China has obtained good development opportunities in the schoolrunning of vocational education group, and has achieved remarkable achievements in the current social background. After systematic analysis and research on the construction of vocational education groups in various regions of China, we have found that in the course of a long term development, the school-running scale of vocational education group has been constantly expanded and extended, which has shown a diversified development trend. What's more, the number of main members is increasing, and the scope of influence and coverage are further expanded and extended, showing obvious competitive advantages in talent training[2]. In the practice of the school-running of vocational education group, it is found that the advantages of the collectivization school-running model is obvious, especially an important way to promote the deep cohesion and fusion of school-enterprise cooperation, combination of learning with working, and substituted post exercitation, which is of great importance to improve the

\footnotetext{
${ }^{1}$ Ministry of Education of the People's Republic of China: Related Information on Collectively Running Schools
}

[EB/OL].http://www.moe.gov.cn/jyb_xwfb/xw_fbh/moe_2069/xwfbh_2018n /xwfb_20180427/sfcl/201804/t20180427_334414.html, 2018/4/27 quality of talent training and promote the stable development of China's regional economy.

\section{The Connection between the School-running of Vocational Education Group and Regional Economy}

The development of the school-running model of vocational education group has an important impact on the construction of the regional economy. After the group realizes the regional distribution development model in China, the regional differences of the school-running of vocational education group are also gradually shown. The development speed of the vocational education group is influenced by the development of regional economy, and also related to the policy orientation made by the government in the process of regional economic development. By the end of 2016, there were 1,406 vocational education groups across the country, among which 983 complete vocational education groups had complete listed data. This has gradually increased geographically and is closely linked to local economic structure and economic development level [3]. Therefore, in order to improve the overall development level of the schoolrunning of vocational education group and provide corresponding talent support for the development of the regional economy, we should gradually build the new path of the linkage development of the vocational education group and regional economy, make them form the development joint force, so as to drive the vocational education group to achieve corresponding development results in school-running in the new era.

\section{The Bottleneck of the Development of the School-running of Vocational Education Group in China}

The school-running of vocational education group in China has gradually fallen into the bottleneck due to the influence of various factors during its development, which has a certain restriction on the improvement of the quality of talent training. The existing problems in the development process of the current school-running of vocational education group are analyzed systematically, and the main findings are as follows: the concept of cooperation in running schools is incomplete, which can not guide the school-running work of vocational education group to develop optimally. Even some industries and enterprises cannot participate in the school-running activities of vocational education group, which will limit the whole quality of running a school; due to lack of a relatively complete cooperative supporting mechanism, the cooperative mechanism of vocational education group in the process of running schools is relatively loose. Moreover, it is impossible to achieve overall coordination and optimal allocation of school resources, and it is difficult to form an intensive effect of school-running activities; the construction of supporting policies of the government is not perfect, and the institutional framework of the group also lacks of scientificity, which will cast a negative impact on the actual developmental level of the vocational education group. Therefore, in the new era, we should correctly understand the problems existing in the school-running of vocational education group during the development of regional economic, formulate scientific and reasonable measures to deal with the problems effectively, ensure that the basic conditions of the school-running of 
vocational education group can be gradually improved, and effectively improve the quality of comprehensive schoolrunning, so that the demand for talents during the process of construction and development of regional economy can be greatly satisfied and the level of regional economic construction can be further improved[4].

\section{The PATH OF LinKage DEVElopment OF THE SCHOOL-RUNNING OF VOCATIONAL EDUCATION GROUP AND REGIONAL ECONOMY}

To explore the linkage development of the running school model of vocational education group and regional economy, we should pay attention to making a comprehensive and systematic analysis in combination of the basic development of regional economy, formulate a scientific and rational linkage development strategy, and strive to form a perfect linkage development planning system, to lay a foundation for the sustained and stable development of regional economy in the new social context.

\section{A. Actively Establishing the Strategic Concept of Group Cooperation and Win-win Development}

In the process of adjusting the school-running model in line with the needs of regional economic construction and development, the vocational education groups should follow the principles of benefit sharing and win-win cooperation to carry out the teaching activities, study development planning and teaching organization planning from the perspective of long-term development, innovate all management works with a global and strategic perspective, to ensure that they can explore opportunities for cooperation and exchanges in promoting regional economic development as a protagonist in the practical exploration of conducting actual teaching guidance activities. On the basis of reforming and innovating the talent training work, the vocational educational groups actively seek opportunities for cooperation, properly define the status of professional personnel training in the group, and effectively improve the overall construction and development effectiveness of the group work [5]. In the work practice, the relevant staff should take the initiative to undertake the important responsibility to promote the development of regional economy and vocational education. On the basis of sharing the benefits of the school-running of vocational education group and cooperation, the corresponding talent training advantages will be formed to promote the construction and development of the group, and to provide effective support for the optimization of regional economic construction activities. The local government departments and relevant organizations must also establish the correct service concept, improve the service quality comprehensively and systematically, so as to implement correct guidance for the school-running work of vocational education group, create internal and external work that is suitable for the optimized development of school-running of vocational education group to build a sound school support system. Based on the development demand of regional economy in the new era, it should ensure that the school-running work of vocational education group can obtain better development results and the work quality of talents training can be further improved.

\section{B. Constructing a Group Management Mode That Can Promote the Benefit Sharing of Multiple Subjects}

It must be clearly recognized that there are significant differences in the interest appeals of different members participating in school-running activities in the process of reforming and innovating the talent training work in combination with the school-running model of vocational education group. The main purpose of government departments participating in collectivization school-running in their work is to train different types and levels of professional and technical talents for the development of regional economy and the stable development of regional society. In the joint school-running model, the vocational education groups hope to promote the improvement of level of education and talent training by using of the application of social resources and social forces, and optimize and adjust the industrial organizations on the basis of cultivating high-quality talents, to provide corresponding talent support for the sustainable development of the group and the stable development of regional economy [6]. Based on defining the interest needs of different interest subjects under the school-running model of vocational education group, we must actively implement group management in the actual school-running organization activities, take into account the interests of different interest subjects, and regard the school as the main body of talent cultivation and optimize the industry development background to meet the needs of enterprises for talents. In this process, we must give play to the macro-control role of government departments, clarify the relationship between different interest subjects under the school-running model of vocational education group by means of administrative measures of government departments, create a good regional economic environment for the development of the school-running of vocational education group, and comprehensively improve the effectiveness of school-running and talent training. On this basis, the vocational education groups also need to strengthen their own service awareness in the process of developing vocational education, take the initiative to participate in the vocational training system, scientifically transform and analyze technological achievements, strive to form a perfect development system under the support of enterprises, government and other related organizations, and effectively improve the comprehensive development effectiveness of talent training.

\section{Completing and Implementing the Supporting Policies}

In the process of actively organizing the development of vocational education groups combining with the demands of regional economic construction and development, the influence of government departments is relatively obvious. The role of government departments in the overall planning for vocational education can be exerted. The appropriate optimization can be made with the help of leading role of government departments, which will further promote the vocational education group to form distinctive development advantages and achieve stable development goals. In the process of promoting the linkage development of vocational education group and regional economy, government departments shall analyze the situation of talent demand under the regional economic development model from the 
perspective of national strategic development plans, then combine the needs of regional economic development for talents, formulate corresponding supporting guidance measures for vocational education group, clearly define the rights and obligations involved in the process of vocational education group education from many perspectives, so as to create a high-quality education environment of vocational education group and improve the actual results of school-running activities. Therefore, with the support of the government, we can effectively avoid the unclear responsibility of the main body and poor overall planning in the process of collectivization school-running, effectively promote the organic linkage of the regional economy and the vocational education group, improve the integrating degree of talent demand in the process of the school-running of vocational education group and regional economy, enhance the effectiveness of the training of talents, and gradually promote the scientific and stable development of the school-running of vocational education group in the new period.

\section{Optimizing the Organizational Structure of the School- running of Vocational Education Group}

The construction and improvement of organizational structure is the main guarantee to promote the optimization of the school-running of vocational education group under the background of developing regional economic. In accordance with the guidance of the system optimization theory, the members of the vocational education group should not only achieve the goal of complement each other's advantages, and implement the cooperation on the basis of promoting the complementary advantages. Through the gradual construction of the board of directors and council, we will provide scientific guidance to the development of the school-running of vocational education group, comprehensively improve the effect of school-running under the function of organizational guarantee, and create conditions for the scientific development of the talent training. Meanwhile, in the process of optimizing the organizational structure, we should pay attention to innovating the organization form, coordinating the relations and tasks between different organizations, making full use of the advantages of the vocational education group in the training of talents, and form a more scientific and perfect talent training system. On the basis of achieving organizational goals, the effectiveness of talent training is also significantly enhanced. Therefore, we can truly realize the goal of the linkage development of the vocational education group and the regional economy based on developing the vocational education group, so as to promote China's regional economy to achieve remarkable achievements in the new period.

\section{CONCLUSION}

In summary, starting from the construction of the vocational education group, we appropriately innovate the work of vocational education, and build a sound vocational education system, so as to form a new development mode of vocational education. On the basis of realizing the joint development of the school-running model of the vocational education group and regional economy, we should give full play to the advantages of combined development of the two to promote the comprehensive improvement of the overall education quality in China. In the process of reforming and innovating vocational education in the new era, we should gradually build a perfect school-running model of vocational education group, improve the pertinence and effectiveness of personnel training work, truly form an effective connection between the talent training of vocational education group and talent demand in the process of regional economic development, provide talent guarantees for the development of regional economic activities, effectively improve the effectiveness of the linkage development of the vocational education group and the regional economy, and promote the steady development of the regional economy.

\section{REFERENCES}

[1] Zhang Lei. The Study of Characteristic Path of Regional Vocational Education Group Integration Development [J]. Liaoning Higher Vocational Technical Institute Journal, 2015(7):22-25. 张磊. 区域型职 教集团一体化发展的特色路径研究[J].辽宁高职学报,2015(7):22-25.

[2] Han Bing. Looking at its Development and Construction Requirements from the Current Situation of Vocational Education Group Activities[J]. Chinese Vocational and Technical Education, 2017 (8): 66-70. 寒冰.从 职教集团活动现状看其发展和建设要求 $[\mathrm{J}]$. 中国职业技术教育, 2017 (8) : 66-70.

[3] Su Guohui. Analysis of SOWT Built by Regional Vocational Education Group and its Countermeasures [J]. Adult Education, 2015(10):66-69. 苏国晖. 区域型职教集团建设的 SOWT 分析及对策 [J].成人教 育, 2015(10):66-69.

[4] Liu Xiaoning, Liu Xiao. The Reality Review and Functional Positioning of the Development of Vocational Education Group [J]. Chinese Vocational and Technical Education, 2016(12):68-73.刘晓宁，刘晓.职 教集团发展的现实审视与功能定位 [J]. 中国职业技术教 育, 2016(12):68-73

[5] Ouyang Min. Research on the Current Situation and Countermeasures of Vocational Education Group Docking the Demand of Regional Economic Development [J]. Continue Education Research, 2015(1):1516. 欧阳旻.职教集团对接区域经济发展需求现状与对策研究 [J].继 续教育研究,2015(1):15-16.

[6] Han Yachao, Yin En, Yang Xiaojun. Talents Cultivation Mode Reform and Innovation of Agriculture-related Higher Vocational Specialties to Serve Regional Economic Development [J]. Modern Agricultural Science and Technology, 2017(22):282-284. 韩亚超,尹恩,杨小军.服务 区域经济发展的高职涉农类专业人才培养模式改革与创新 [J].现代 农业科技,2017(22):282-284.

Hu Qing, Yi Biao. Research on the Cooperation Model of SchoolRunning between College-Enterprise of Vocational Education Group [J]. Mechanical Vocational Education, 2015(11):1-4.胡清,易禾.职教集团 校企合作办学模式研究[J].机械职业教育,2015(11):1-4. 